p-ISSN: 1410-0029; e-ISSN2549-6786

Agrin Vol. 25, No. 1, April 2021

\title{
MODEL ADSORPSI ISOTERM ARANG AKTIF KULIT KOPI PADA PENURUNAN WARNA AIR LIMBAH PENGOLAHAN KOPI
}

\section{Adsorption Isotherm Model of Coffee Pulp Activated Carbon In Coffee Wastewater Color Reduction}

\author{
Elida Novita ${ }^{*}$,Sri Wahyuningsih', \\ Nur Shodiqotul Kamil ${ }^{1}$, dan Hendra Andiannanta Pradana ${ }^{2}$ \\ ${ }^{1}$ Teknik Pertanian, Fakultas Teknologi Pertanian, Universitas Jember \\ ${ }^{2}$ Pengelolaan Sumber Daya Air Pertanian, Pascasarjana, Universitas Jember \\ J1. Kalimantan 37, Kampus Tegal Boto Jember 68121 \\ *Alamat korespondensi: elida_novita.ftp@unej.ac.id
}

\begin{abstract}
ABSTRAK
Pengolahan kopi menghasilkan air limbah kopi dan limbah padat berupa kulit kopi. Air limbah pengolahan kopi mengandung flavonoid yang berpengaruh terhadap warna coklat gelap pada air limbah pengolahan kopi. Apabila air limbah pengolahan kopi dibuang langsung ke badan air tanpa adanya pengolahan, akan mengganggu ekosistem perairan. Kulit kopi mengandung selulosa dan senyawa organik sehingga berpotensi untuk dijadikan sebagai arang aktif. Penelitian ini bertujuan untuk menganalisis karakteristik dan model adsorpsi isoterm arang aktif kulit kopi terhadap penurunan warna pada air limbah pengolahan kopi. Tahapan penelitian dibagi menjadi dua yaitu pembuatan arang aktif dan penentuan model adsorpsi isoterm. Arang aktif kulit kopi yang digunakan diaktivasi dengan senyawa $\mathrm{NaOH} 1 \mathrm{M}$ dan dikarakterisasi berdasarkan SNI-06-3730-1995 dengan parameter kadar air, kadar abu, dan daya serap $\mathrm{I}_{2}$. Selanjutnya, proses adsorpsi arang aktif dianalisis dengan metode adsorpsi isoterm berdasarkan persamaan Langmuir dan Freundlich. Pemilihan persamaan model isoterm berdasarkan nilai Root Square Mean Error (RSME) yang paling kecil. Arang aktif kulit kopi yang dihasilkan telah memenuhi SNI0603730-1995 dengan kadar air sebesar 3,43 \%; kadar abu 2,30 \%; dan daya serap $\mathrm{I}_{2} 15.231,6 \mathrm{mg} / \mathrm{g}$. Adapun adsorpsi pada penelitian ini mengikuti model isoterm Langmuir dengan nilai RSME sebesar 0,005.
\end{abstract}

Kata kunci: arang aktif, adsorben alami, kesetimbangan, model Langmuir, model Freundlich

\begin{abstract}
The coffee processing produces coffee wastewater and pulp coffee waste. Coffee wastewater contains a flavonoid compound that affects the dark brown color of the coffee wastewater. When the coffee wastewater directly discharged into water, it can be detrimental to aquatic ecosystem. The coffee pulp contains cellulose and organic compounds that potentially can be used as activated carbon. The study aims to determine the characteristics and adsorption isotherm model of coffee pulp activated carbon to reduce the color of coffee wastewater. The stages of study are divided into two stages, namely the production of activated carbon and the determination of the adsorption isotherm model. Coffee pulp activated carbon used is activated with NaOH $1 \mathrm{M}$ compound and its characteristic based on SNI-06-3730-1995 with parameters i.e. moisture content, ash content, and absorbability of Iodine. Next, the adsorption process was analyzed by Langmuir and Freundlich adsorption isotherm model. The model selection considered root square mean error (RSME). Coffee pulp-activated carbon product has fulfilled SNI-0603730-1995 with a moisture content is 3.43\%; $2.30 \%$ ash content; and absorbability of Iodine is $15,231.6 \mathrm{mg} / \mathrm{g}$. The adsorption process in this study following the Langmuir isotherm model with RSME was 0.005.
\end{abstract}

Keywords: activated carbon, equilibrium, Freundlich model, Langmuir model, natural adsorbent

\section{PENDAHULUAN}

Pengolahan kopi dibagi menjadi dua yaitu pengolahan secara basah dan kering. Pengolahan biji kopi secara basah menghasilkan limbah padat berupa kulit kopi sebesar $200 \mathrm{~kg} /$ ton dan memerlukan air sebesar 20 L/kg kopi. Novita et al. (2019) menyatakan air limbah dari pengolahan kopi sebesar $50 \%$ dari total air yang digunakan. Adapun limbah lainnya berupa 
kulit kopi belum dimanfaatkan secara optimal. Padahal, kulit kopi mengandung bahan organik dan senyawa yang mampu menyerap polutan yang berpotensi dijadikan sebagai produk bernilai tambah (Cheruiyot et al., 2019; Widyotomo, 2013). Salah satu pemanfaatan kulit kopi adalah sebagai bahan baku pembuatan arang aktif.

Selain limbah padat, pengolahan kopi menghasilkan air limbah. Air limbah pengolahan kopi berbau tidak sedap, berwarna cokelat dan akan berubah warna menjadi hitam beberapa saat kemudian. Selain menurunkan nilai estetika, warna cokelat yang gelap dapat mengganggu proses fotosintesis tanaman yang berada di dalam air. Oleh karena itu, air limbah pengolahan kopi harus diolah terlebih dahulu sebelum dibuang ke lingkungan. Upaya ini dilakukan agar warnanya tidak terlalu pekat sehingga mengurangi pencemaran lingkungan (Riadi et al., 2011). Salah satu teknologi pengolahan limbah cair yang efektif adalah adsorpsi menggunakan karbon aktif.

Karbon telah dikenal sejak abad pertengahan yang berfungsi menghilangkan zat terlarut yang terkandung di dalam cairan. Pemahaman tentang prosesnya telah banyak dipelajari (Droste and Gehr, 2018). Penggunaan arang aktif merupakan salah satu cara yang telah banyak dilakukan sebagai penetralisir warna dan polutan pada air limbah (Tamad \& Maryanto, 2014).
Arang aktif dari ampas tebu dapat mereduksi zat warna procion merah pada air limbah industri songket mencapai 76,3 \% (Sari et al., 2017). Pada studi lainnya yang menggunakan arang aktif dari sampah plastik, dapat menurunkan kandungan fosfat pada air limbah laundry sekitar $50 \%$ (Wardhana et al., 2013).

Arang aktif dapat dibuat dari bahan yang mengandung karbon antara lain kayu, batu bara, lignit, dan batok kelapa. Secara umum, adsorben alami berasal dari limbah pengolahan komoditi pertanian (Ukanwa et al., 2019). Kualitas arang aktif dapat ditentukan dari jenis bahan bakunya. Arang aktif dari bahan yang berbeda akan menghasilkan kualitas yang berbeda. Saat ini telah ada berbagai macam versi standar arang aktif yang telah ditetapkan. Salah satu versi standar arang aktif yang telah ditetapkan yaitu SNI 06-3730-1995 (BSN, 1995). Selain jenis bahan baku, zat pengaktif juga berpengaruh terhadap mutu arang aktif. Zat pengaktif dapat berupa senyawa kimia yang bersifat asam atau basa. Adapun beberapa bahan aktivasi karbon yang umum digunakan yaitu $\mathrm{NaOH}$, $\mathrm{H}_{2} \mathrm{SO}_{4}$, dan $\mathrm{HCl}$ (Mattel, 1991).

Kulit kopi dapat digunakan sebagai bahan dasar yang mudah didapatkan dalam pembuatan arang aktif (Aman et al., 2018). Aplikasi kulit kopi sebagai limbah pertanian sebagai bahan baku adsorben lebih efektif daripada limbah pertanian 
lainnya (Getachew et al., 2015; Gonçalves et al., 2013). Kualitas adsorben dikarakterisasi berdasarkan SNI 06-37301995 (BSN, 1995). Adapun kapasitas optimum kinerja adsorben didekati dengan pola penyerapan polutan pada air limbah yang didefinisikan dalam model adsorpsi. Model adsorpsi isoterm yang biasa digunakan yaitu isoterm Langmuir dan Freundlich (Puspitasari et al., 2017; Nekoo $\&$ Fatemi, 2013). Tujuan dari penelitian ini yaitu menguji karakteristik arang aktif kulit kopi sesuai dengan SNI 06-3730-1995 dan menganalisis model adsorpsi isoterm arang aktif kulit kopi terhadap zat warna pada air limbah pengolahan kopi. Hasil penelitian ini diharapkan dapat digunakan sebagai alternatif penanganan air limbah pengolahan kopi secara adsorpsi menggunakan adsorben alami dan pemanfaatan limbah kulit kopi sebagai karbon aktif.

\section{METODE PENELITIAN}

Penelitian dilakukan di Laboratorium Teknik Pengendalian dan Konservasi Lingkungan (TPKL), Laboratorium Enjinering Hasil Pertanian (EHP) Jurusan Teknik Pertanian dan Laboratorium Mikrobiologi Pangan Hasil Pertanian (MPHP) Jurusan Teknologi Hasil Pertanian, Fakultas Teknologi Pertanian, Universitas Jember. Penelitian dilakukan pada bulan Desember 2018-April 2019.
Bahan yang diperlukan pada penelitian ini antara lain kulit buah kopi robusta hasil pengolahan kering kopi sebagai adsorben yang diperoleh dari agroindustri kopi di Desa Sidomulyo Kecamatan Silo Kabupaten Jember. Sampel air limbah pengolahan kopi sintetik diperoleh dengan membuat larutan kopi menggunakan bubuk kopi sehingga memiliki kandungan yang setara dengan air limbah pengolahan kopi (bubuk kopi diperoleh dari industri kopi di Desa Sidomulyo) dan larutan kimia (air suling bebas ion, $\mathrm{NaOH} 1 \mathrm{M}, \mathrm{I}_{2} 0,1 \mathrm{~N}, \mathrm{Na}_{2} \mathrm{~S}_{2} \mathrm{O}_{3} 0,1$ $\mathrm{N}$ dan Amilum $1 \%$ ).

Alat yang digunakan pada penelitian antara lain oven Memmert, neraca analitik Matrix, desikator, mesin penggiling kopi, ayakan 100 mesh, spektrofotometer UVVis, alat adsorpsi, cawan porselin $250 \mathrm{~mL}$, gelas kimia $50 \mathrm{~mL}, 100 \mathrm{~mL}$, dan $500 \mathrm{~mL}$, pH meter, kuvet, pipet tetes, tissu, kertas saring Whatman no. 41, stopwatch, COD meter Hanna, dan tanur Daeyang.

Parameter yang diamati pada penelitian ini yaitu kadar air, kadar abu, daya serap $\mathrm{I}_{2}$, dan nilai absorbansi (warna) pada air limbah pengolahan kopi.

Penelitian ini terdiri dari beberapa tahapan yaitu pembuatan arang aktif, karakterisasi arang aktif kulit kopi, pembuatan sampel air limbah pengolahan kopi sintetik, dan penentuan model adsorpsi isoterm. 


\section{Pembuatan Arang Aktif}

Pembuatan arang aktif terdiri dari beberapa tahapan yaitu:

1) Dehidrasi (Pengeringan)

Proses dehidrasi dilakukan dengan memasukkan kulit kopi ke dalam oven selama 24 jam dengan suhu $105{ }^{\circ} \mathrm{C}$ atau dapat pula dilakukan dengan cara lain yaitu dijemur langsung di bawah sinar matahari. Proses dehidrasi bertujuan untuk mengurangi kadar air yang terkandung di dalam kulit kopi (Puspitasari et al., 2017).

\section{2) Karbonasi}

Kulit kopi yang sudah berkurang kadar airnya, dikarbonasi di dalam tungku pembakaran selama 5 jam dengan suhu $400{ }^{\circ} \mathrm{C}$. Proses karbonasi ini bertujuan untuk menghilangkan senyawa yang mudah menguap. Dalam proses karbonasi, selulosa dipecah atau diuraikan menjadi karbon (Pambayun et al., 2013).

\section{3) Pengecilan Ukuran}

Kulit kopi yang sudah menjadi arang kemudian digerus dan diayak menggunakan ayakan 100 mesh. Ukuran tersebut digunakan karena daya serap adsorben lebih besar (Yeni et al., 2008).

\section{4) Aktivasi}

Arang kulit kopi yang telah diayak kemudian diaktivasi dengan larutan $\mathrm{NaOH} 1 \mathrm{M}$ dengan perbandingan 1:3 yaitu $100 \mathrm{~g}$ karbon : $300 \mathrm{~mL}$ larutan
$\mathrm{NaOH} 1$ M. Selanjutnya direndam selama 24 jam dengan larutan $\mathrm{NaOH} 1$ M tersebut.

5) Penetralan $\mathrm{pH}$ Arang Aktif

Penetralan dilakukan dengan mencuci arang aktif menggunakan akuades sampai $\mathrm{pH}$ netral, yaitu 7. Alat yang digunakan untuk mengukur $\mathrm{pH}$ yaitu $\mathrm{pH}$ meter. Penetralan $\mathrm{pH}$ dilakukan untuk menghilangkan sisa aktivator $\mathrm{NaOH}$ sehingga tidak menutupi permukaan pori-pori arang aktif (Kurniawan \& Wicaksana, 2008).

\section{Karakterisasi Arang Aktif}

Kualitas arang aktif dapat diketahui dengan melakukan pengujian terhadap arang aktif tersebut. Karakterisasi arang aktif ini berdasarkan SNI 06-3730-1995 tentang arang aktif teknis (BSN, 1995). Karakterisasi arang aktif meliputi pengujian kadar abu, pengujian kadar air, dan daya serap terhadap Iodium $\left(\mathrm{I}_{2}\right)$.

\section{Pengujian Kadar Air}

Prosedur pengujian kadar air dilakukan dengan menimbang arang aktif kulit kopi sebanyak $1 \mathrm{~g}$ dan dimasukkan ke dalam cawan porselin yang telah diketahui massanya. Selanjutnya, cawan yang berisi arang aktif dipanaskan di dalam oven dengan suhu $105{ }^{\circ} \mathrm{C}$ selama \pm 1 jam. Kemudian arang aktif kulit kopi didinginkan dalam desikator selama 15 menit dan ditimbang sampai massanya 
tetap. Kadar air ditentukan menggunakan persamaan 1 .

$$
\text { Kadar air }(\%)=\frac{(a-b)}{a} \times 100 \%
$$

\section{Keterangan:}

$\mathrm{a}=$ massa sampel sebelum pemanasan $(\mathrm{g})$

$\mathrm{b}=$ massa sampel setelah pemanasan $(\mathrm{g})$

\section{Pengujian Kadar Abu}

Prosedur pengujiannya yaitu arang aktif kulit kopi sebanyak $1 \mathrm{~g}$ dimasukkan ke dalam cawan porselin yang telah diketahui massanya. Kemudian cawan tersebut dipanaskan di dalam tanur selama 4 jam dengan suhu $650{ }^{\circ} \mathrm{C}$. Arang aktif yang telah dipanaskan, kemudian didinginkan di dalam desikator selama 15 menit dan ditimbang massanya sampai tetap. Pengukuran dilakukan tiga kali pengulangan. Kadar abu dapat dihitung menggunaan persamaan 2 .

Kadar abu $(\%)=\frac{b}{a} \times 100 \%$

Keterangan:

$\mathrm{a}=$ massa sampel sebelum pemanasan $(\mathrm{g})$ $\mathrm{b}=$ massa sampel setelah pemanasan $(\mathrm{g})$

\section{Pengujian Daya Serap Iodium (I2)}

Pengujian terhadap daya serap iodium dilakukan dengan menimbang arang aktif sebanyak $5 \mathrm{~g}$ dan dicampurkan dengan 100 $\mathrm{mL}$ larutan Iodium $0,1 \quad \mathrm{~N}$. Campuran tersebut dikocok selama 15 menit. Selanjutnya campuran tersebut dipindahkan ke dalam tabung sentrifugal sampai arang aktif mengendap. Kemudian diambil $10 \mathrm{~mL}$ cairan tersebut dan dititrasi dengan larutan
$\mathrm{Na}_{2} \mathrm{~S}_{2} \mathrm{O}_{3} 0,1$ N. Jika warna kuning pada larutan mulai pucat, tambahkan larutan amilum $1 \%$ sebagai indikator. Titrasi kembali dilanjutkan sampai warna biru tua berubah menjadi bening. Nilai daya serap iodium dihitung berdasarkan persamaan 3 .

$$
\mathrm{D}=\frac{\left(\left(V 2-\frac{N 1 \times V 1}{N 2}\right) \times 12,68 \times 2,5\right)}{W}
$$

Keterangan:

D = Daya adsorb $\mathrm{I}_{2}(\mathrm{mg} / \mathrm{g})$

$\mathrm{N}_{1}=$ normalitas larutan $\mathrm{Na}_{2} \mathrm{~S}_{2} \mathrm{O}_{3}(0,1$ $\mathrm{N})$

$\mathrm{N}_{2}=$ normalitas larutan $\mathrm{I}_{2}(0,1 \mathrm{~N})$

$\mathrm{V}_{1}=$ volume titran [larutan $\mathrm{Na}_{2} \mathrm{~S}_{2} \mathrm{O}_{3}$ yang dibutuhkan untuk titrasi $(\mathrm{mL})]$

$\mathrm{V}_{2} \quad=$ volume titran $(10 \mathrm{~mL})$

2,5 = faktor pengenceran

12,69 = massa $\mathrm{I}_{2}$ yang sesuai dengan 1 mL larutan $\mathrm{Na}_{2} \mathrm{~S}_{2} \mathrm{O}_{3} 0,1 \mathrm{~N}$

$\mathrm{W}=$ massa arang aktif $(0,25 \mathrm{~g})$

\section{Pembuatan Air Limbah Pengolahan Kopi Sintetik}

Air limbah pengolahan kopi sintetik dibuat dengan mencampurkan bubuk kopi dengan air. Air limbah pengolahan kopi sintetik ini dibuat dengan 10 variasi konsentrasi larutannya yaitu 1-10 g/L dengan interval $1 \mathrm{~g} / \mathrm{L}$. Selanjutnya, masingmasing sampel air limbah sintetik tersebut diukur kadar COD nya menggunakan COD meter merk Hanna. Pengukuran COD ini, digunakan sebagai pendekatan nilai COD pada air limbah pengolahan kopi yang asli. 


\section{Penentuan Model Adsorpsi Isoterm}

Penentuan model adsorpsi isoterm arang aktif kulit kopi terhadap air limbah pengolahan kopi sintetik terdiri dari beberapa tahap yaitu pengukuran absorbansi warna coklat awal, adsorpsi arang aktif, dan pembuatan grafik yang merujuk pada kajian Murtihapsari et al. (2017) dan Wijayanti \& Kurniawati (2019).

\section{Pengukuran Absorbansi Warna Cokelat} Awal

Air limbah pengolahan kopi sintetik

yang digunakan pada pengukuran absorbansi warna coklat awal yaitu dengan 10 variasi konsentrasi larutan $1000 \mathrm{mg} / \mathrm{L}-$ $5500 \mathrm{mg} / \mathrm{L}$ dengan interval $500 \mathrm{mg} / \mathrm{L}$. Pengukuran ini dilakukan pada panjang gelombang maksimum yang telah dicari pada proses sebelumnya. Pengukuran dilakukan menggunakan alat spektrofotometer UV-Vis.

\section{Adsorpsi Arang Aktif}

Arang aktif kulit kopi sebanyak $10 \mathrm{~g}$ dimasukkan ke dalam gelas reaktor adsorpsi. Kemudian ditambahkan air limbah pengolahan kopi sintetik dengan 10 variasi konsentrasi sebanyak $100 \mathrm{~mL}$. Campuran kemudian diaduk dan didiamkan selama 90 menit. Selanjutnya campuran tersebut disaring dengan kertas saring. Filtrat yang dihasilkan kemudian diukur absorbansi dengan spektrofotometer UVVis pada panjang gelombang maksimum yang sama. Pengukuran dilakukan dengan 3 kali pengulangan.

\section{Pembuatan Grafik}

Representasi kemampuan arang aktif dalam memperbaiki kualitas air limbah pengolahan kopi dilakukan menggunakan metode adsorpsi isoterm. Perhitungan konsentrasi kesetimbangan menggunakan persamaan 4.

$$
\mathrm{Q}_{\mathrm{e}}=\frac{(\mathrm{Co}-\mathrm{C})}{\mathrm{M}} \mathrm{V}
$$

Keterangan:

$\mathrm{Q}_{\mathrm{e}}=$ konsentrasi kesetimbangan, yang terserap arang aktif $(\mathrm{mg} / \mathrm{g})$

$\mathrm{C}_{\mathrm{o}}=\operatorname{kosentrasi}$ awal $(\mathrm{mg} / \mathrm{L})$

$\mathrm{C}=$ konsentrasi kesetimbangan $(\mathrm{mg} / \mathrm{L})$

$\mathrm{M}=$ massa arang aktif di dalam reaktor $(\mathrm{g})$

$\mathrm{V}=$ volume sampel $(\mathrm{L})$

Data kesetimbangan yang didapatkan kemudian diformulasikan ke dalam model adsorpsi isoterm Langmuir dan Freundlich. Formula isoterm Langmuir dapat dilihat pada persamaan 5 .

$$
\mathrm{Q}_{\mathrm{e}}=\frac{\mathrm{Qo} \mathrm{KC}}{\mathrm{KC}+1}
$$

Keterangan:

$\mathrm{Q}_{\mathrm{e}}=$ konsentrasi kesetimbangan, yang terserap arang aktif $(\mathrm{mg} / \mathrm{g})$

$\mathrm{Q}_{\mathrm{o}}=$ jumlah maksimum zat terlarut yang dapat teradsorpsi $(\mathrm{mg} / \mathrm{g})$

$\mathrm{K}$ = konstanta Langmuir

$\mathrm{C}=$ konsentrasi kesetimbangan $(\mathrm{mg} / \mathrm{L})$

Untuk membuat grafik isoterm

Langmuir, maka persamaan 5, harus dilinearkan terlebih dahulu, sehingga menjadi persamaan 6 berikut: 


$$
1 / \mathrm{Q}_{\mathrm{e}}=1 / \mathrm{Q}_{\mathrm{o}}+\left(1 / \mathrm{Q}_{\mathrm{o}} \cdot \mathrm{K}\right)(1 / \mathrm{C})
$$

Dari persamaan 6, apabila diplotkan pada grafik maka akan membentuk garis lurus. Perpotongan dengan sumbu y menyatakan nilai $1 / Q_{o}$ dan kemiringan dari garis menyatakan nilai $1 / Q_{o}$ K. Formula Freundlich disajikan pada persamaan 7 .

$$
\mathrm{Q}_{\mathrm{e}}=\mathrm{K}_{\mathrm{f}} \mathrm{C}^{1 / \mathrm{n}}
$$

Keterangan: $\mathrm{K}_{\mathrm{f}}$ dan $\mathrm{n}$ adalah konstan

Untuk membuat grafik Isoterm Freundlich maka persamaan 7 harus dilinearkan terlebih dahulu, sehingga menjadi persamaan 8 .

$$
\log \mathrm{Q}_{\mathrm{e}}=\log \mathrm{K}_{\mathrm{f}}+1 / \mathrm{n} \log \mathrm{C}
$$

Dari Persamaan 7, apabila diplotkan pada grafik maka akan membentuk garis lurus. Perpotongan dengan sumbu y menyatakan nilai $\log \mathrm{K}_{\mathrm{f}}$ dan kemiringan dari garis menyatakan nilai $1 / \mathrm{n}$.

Dari kedua grafik tersebut, kemudian dicari nilai koefisien regresi linier $\left(\mathrm{R}^{2}\right)$ untuk mengetahui model isoterm yang paling sesuai dengan proses adsopsi arang aktif kulit kopi pada air limbah pengolahan kopi. Nilai koefisien regresi linier $\left(\mathrm{R}^{2}\right)$ yang terbesar merupakan acuan yang digunakan untuk mengetahui model isoterm tersebut. Selanjutnya, apabila sudah diketahui model isoterm yang sesuai maka dapat diketahui kapasitas adsorpsi maksimum yang dapat diserap oleh arang aktif kulit kulit kopi.

Selanjutnya, model regresi dari isoterm Langmuir dan Freundlich dapat dievaluasi dengan menghitung nilai Root
Mean Squared Error (RMSE). RMSE dihitung dengan mengkuadratkan selisih antara nilai perkiraan dengan nilai hasil observasi (Widayati, 2013). Persamaan RMSE dapat dilihat pada persamaan 9 berikut:

$$
\operatorname{RMSE}=\left[\sum_{\mathrm{i}=1}^{\mathrm{N}}\left(\mathrm{z}_{\mathrm{fi}}-\mathrm{z}_{\mathrm{oi}}\right)^{2} / \mathrm{N}\right]^{1 / 2}
$$

Keterangan:

$\mathrm{N}$ = banyaknya data

$\mathrm{z}_{\mathrm{fi}}=$ data prediksi

$\mathrm{z}_{\mathrm{oi}}=$ data observasi

\section{HASIL DAN PEMBAHASAN}

\section{Karakterisasi Arang Aktif}

Arang aktif yang dihasilkan dikarakterisasi mengikuti SNI 06-37301995. Tabel 1 memperlihatkan hasil karakterisasi arang aktif dari kulit buah kopi. Nilai kadar air, kadar abu, dan daya serap terhadap $\mathrm{I}_{2}$ arang aktif kulit kopi telah memenuhi SNI 06-3730-1995. Kadar air dihitung untuk mengetahui sifat higroskopis arang aktif kulit kopi. Tinggi rendahnya nilai kadar air menunjukkan berapa banyak air yang menutupi pori-pori yang terdapat pada arang aktif kulit kopi. Semakin rendah kadar air, akan semakin banyak ruang pada pori untuk mengikat adsorbat sehingga mengoptimalkan proses adsorpsi (Malik, 2013).

Kadar abu dihitung untuk mengetahui kandungan sisa mineral yang tertinggal dalam arang aktif kulit kopi pada proses karbonisasi dan aktivasi. Sisa mineral akan 
Tabel 1. Karakterisasi arang aktif kulit kopi

\begin{tabular}{lcc}
\hline \multicolumn{1}{c}{ Uraian } & Hasil penelitian & $\begin{array}{c}\text { (Badan Standarisasi Nasional } \\
(\text { BSN), 1995) }\end{array}$ \\
\hline Kadar air $(\%)$ & 3,43 & Maks. 15 \\
Kadar abu (\%) & 2,30 & Maks. 10 \\
Daya serap terhadap $\mathrm{I}_{2}(\mathrm{mg} / \mathrm{g})$ & 15231,60 & Min. 750 \\
\hline
\end{tabular}

Tabel 2. Data absorbansi pada berbagai variasi konsentrasi air limbah pengolahan kopi sintetik

\begin{tabular}{cccc}
\hline $\mathrm{C}_{\mathrm{o}}(\mathrm{mg} / \mathrm{L})$ & Absorbansi Awal & $\mathrm{C}(\mathrm{mg} / \mathrm{L})$ & Absorbansi Akhir \\
\hline 1000 & 0,325 & 145,78 & 0,110 \\
1500 & 0,433 & 265,22 & 0,133 \\
2000 & 0,563 & 373,00 & 0,155 \\
2500 & 0,640 & 597,44 & 0,200 \\
3000 & 0,752 & 935,78 & 0,268 \\
3500 & 0,836 & 1156,89 & 0,312 \\
4000 & 0,945 & 1344,11 & 0,349 \\
4500 & 1,077 & 1314,67 & 0,343 \\
5000 & 1,228 & 1454,11 & 0,371 \\
5500 & 1,395 & 1692,44 & 0,419 \\
\hline
\end{tabular}

Keterangan: $\mathrm{C}_{\mathrm{o}}=$ konsentrasi air limbah pengolahan kopi awal, $\mathrm{C}=$ konsentrasi air limbah pengolahan kopi akhir.

menyumbat pori-pori arang aktif sehingga dapat mengurangi kapasitas adsorpsi (Herlandien, 2013).

Daya serap terhadap Iodium diuji untuk mengetahui besarnya kemampuan atau daya serap arang aktif kulit kopi terhadap air limbah pengolahan kopi. Pada permukaan arang aktif terdapat situs aktif yang berfungsi untuk mengikat adsorbat. Situs aktif tersebut diuji daya serapnya menggunakan larutan Iodium. Semakin besar daya serap arang aktif terhadap Iodium maka semakin baik daya serapnya pada proses adsorpsi. Perlakuan aktivasi karbon aktif meningkatkan luas permukaan pori-porinya sehingga memiliki daya serap yang baik terhadap polutan pada air limbah (Sari et al., 2017).

\section{Adsorpsi Isoterm}

Tabel 2 menunjukkan bahwa saat proses adsorpsi berlangsung, pori-pori pada adsorben kulit kopi dapat mengikat zat warna yang terdapat pada air limbah pengolahan kopi sintetik. Hal ini dapat dilihat pada absorbansi awal air limbah pengolahan kopi memiliki nilai yang lebih besar dari nilai absorbansi akhir. Selisih dari nilai absorbansi awal dan akhir menunjukkan bahwa terdapat zat yang terikat pada arang aktif.

Hal ini juga dapat dilihat dari perubahan warna yang terjadi, pada saat sebelum dan sesudah proses adsorpsi warna air limbah pengolahan kopi terlihat berbeda yaitu warna sebelum proses adsorpsi lebih gelap dari warna setelah proses adsorpsi. 
Saat adsorben arang aktif kulit kopi dikontakkan dengan air limbah pengolahan kopi, maka terdapat zat yang terikat pada arang aktif. Jumlah zat yang terikat pada arang aktif tersebut akan bertambah naik secara bertahap sampai mencapai keadaan setimbang. Proses penyerapan tersebut dinyatakan dengan adsorpsi isoterm.

Adsorpsi isoterm menjelaskan hubungan antara jumlah atau konsentrasi adsorbat (zat yang teradsorpsi) yang terakumulasi pada adsorben (karbon aktif) dan konsentrasi kesetimbangan dari adsorbat terlarut (Droste \& Gehr, 2018). Proses adsorpsi arang aktif kulit kopi terhadap air limbah pengolahan kopi sintetik didapatkan data kapasitas adsorpsi (Qe) yang disajikan pada Tabel 3. Kapasitas adsorpsi menyatakan banyaknya konsentrasi zat teradsorpsi (mg) per massa arang aktif kulit kopi (g). Berdasarkan data kapasitas adsorpsi pada Tabel 3. dapat dibuat grafik hubungan konsentrasi larutan air limbah pengolahan kopi (Co) dengan zat warna coklat yang terserap oleh arang aktif kulit kopi (Qe).

Gambar 1 menyajikan bertambahnya nilai konsentrasi larutan kopi awal seiring dengan bertambah tingginya zat warna cokelat yang teradsorpsi oleh arang aktif kulit kopi. Konsentrasi yang semakin meningkat menyebabkan daya dorong molekul adsorbat untuk terikat pada permukaan adsorben hingga mencapai keadaan setimbang. Hal ini sesuai dengan teori yang menyatakan semakin besar konsentrasi larutan, maka semakin banyak jumlah zat terlarut yang teradsorpsi sehingga tercapai kesetimbangan tertentu, dimana laju zat yang diserap sama dengan zat yang dilepas dari adsorben pada suhu tertentu (Mattel, 1991).

Dua model pendekatan adsorpsi isoterm yang digunakan untuk menentukan pola adsorpsi zat warna air limbah pengolahan kopi pada permukaan arang aktif yaitu isoterm Langmuir dan Freundlich (Murtihapsari et al., 2017; Wijayanti \& Kurniawati, 2019). Penentuan pola adsorpsi isoterm Langmuir dilakukan berdasarkan persamaan 5 sehingga dapat dibuat grafik 1/Qe versus $1 / \mathrm{C}$ dan dapat diketahui nilai koefisien persamaan garis lurusnya. Data yang didapatkan untuk isoterm Langmuir dapat dilihat pada Tabel 4 dan grafik isoterm Langmuir dapat dilihat pada Gambar 2.

Penentuan pola adsorpsi isoterm Freundlich dilakukan berdasarkan persamaan 7 sehingga dapat dibuat grafik Log Qe versus Log C dan dapat diketahui nilai koefisien persamaan garis lurusnya. Data yang didapatkan untuk isoterm Freundlich dapat dilihat pada Tabel 5 dan grafik isoterm Freundlich dapat dilihat pada Gambar 3. 
Tabel 3. Data kapasitas adsorpsi variasi konsentrasi air limbah pengolahan kopi sintetik

\begin{tabular}{cc}
\hline Co $(\mathrm{mg} / \mathrm{L})$ & Qe $(\mathrm{mg} / \mathrm{g})$ \\
\hline 1000 & 8,542 \\
1500 & 12,348 \\
2000 & 16,270 \\
2500 & 19,026 \\
3000 & 20,642 \\
3500 & 23,431 \\
4000 & 26,559 \\
4500 & 31,853 \\
5000 & 35,459 \\
5500 & 38,076 \\
\hline Keterangan: $\mathrm{Qe}=$ yang terserap \\
\multicolumn{2}{c}{ adsorben }
\end{tabular}

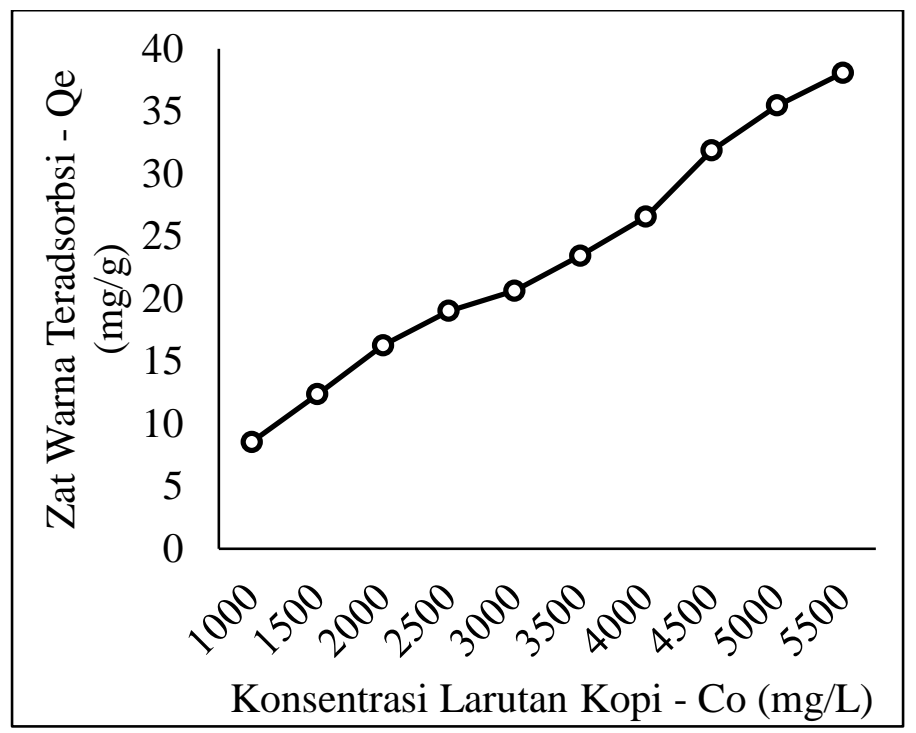

Gambar 1. Grafik penyerapan zat warna cokelat

Tabel 4. Data isoterm Langmuir

\begin{tabular}{ccc}
\hline Co $(\mathrm{mg} / \mathrm{L})$ & $1 / \mathrm{Qe}$ & $1 / \mathrm{C}$ \\
\hline 1000 & 0,117 & 0,00686 \\
1500 & 0,081 & 0,00377 \\
2000 & 0,061 & 0,00268 \\
2500 & 0,053 & 0,00167 \\
3000 & 0,048 & 0,00107 \\
3500 & 0,043 & 0,00086 \\
4000 & 0,038 & 0,00074 \\
4500 & 0,031 & 0,00076 \\
5000 & 0,028 & 0,00069 \\
5500 & 0,026 & 0,00059 \\
\hline
\end{tabular}

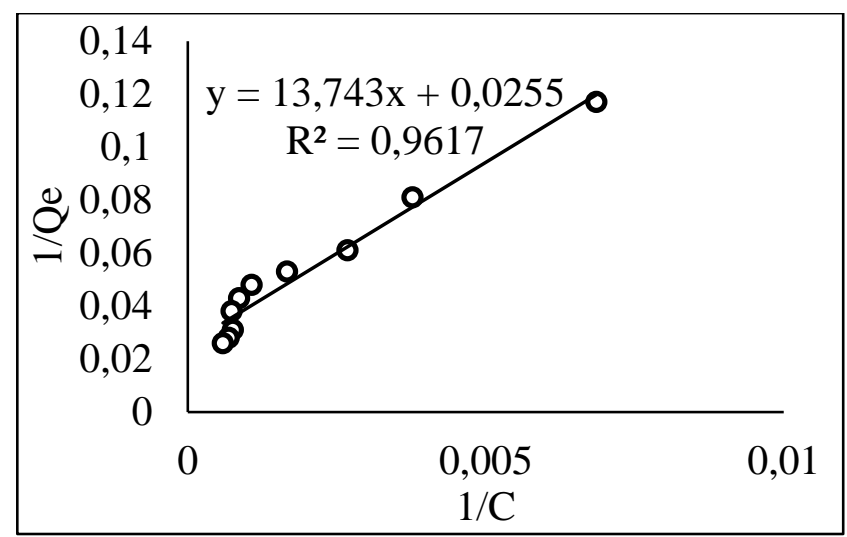

Tabel 5. Data isoterm Freundlich

\begin{tabular}{ccc}
\hline Co $(\mathrm{mg} / \mathrm{L})$ & $\log \mathrm{C}$ & $\log \mathrm{Qe}$ \\
\hline 1000 & 2,164 & 0,932 \\
1500 & 2,424 & 1,092 \\
2000 & 2,572 & 1,211 \\
2500 & 2,776 & 1,279 \\
3000 & 2,971 & 1,315 \\
3500 & 3,063 & 1,370 \\
4000 & 3,128 & 1,424 \\
4500 & 3,119 & 1,503 \\
5000 & 3,163 & 1,550 \\
5500 & 3,229 & 1,581 \\
\hline
\end{tabular}

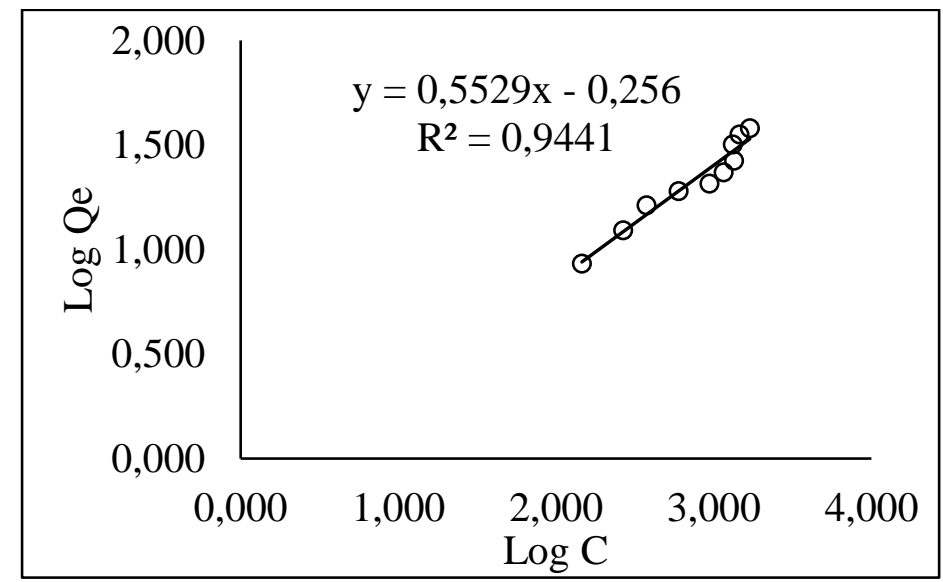

Gambar 3. Grafik isoterm Freundlich

Tabel 6. Parameter adsorpsi isoterm Langmuir dan Freundlich

\begin{tabular}{ccc}
\hline Isoterm & Parameter & Nilai \\
\hline Langmuir & $\mathrm{Q}_{\mathrm{o}}(\mathrm{mg} / \mathrm{g})$ & 39,0625 \\
& $\mathrm{~K}(\mathrm{~L} / \mathrm{mg})$ & 0,00186 \\
Freundlich & $\mathrm{K}_{\mathrm{f}}(\mathrm{mg} / \mathrm{g})$ & 0,55501 \\
& $\mathrm{n}(\mathrm{L} / \mathrm{mg})$ & 1,8089725 \\
\hline
\end{tabular}


Tabel 7. Hasil Perhitungan RMSE

\begin{tabular}{cc}
\hline Model & RMSE \\
\hline Isoterm Langmuir & 0,005 \\
Isoterm Freundlich & 0,046 \\
\hline
\end{tabular}

Berdasarkan nilai koefisien regresi linier $\left(\mathrm{R}^{2}\right)$ pada masing-masing grafik di atas, grafik isoterm Langmuir memberikan nilai $\mathrm{R}^{2}$ yang tidak jauh berbeda dengan nilai $\mathrm{R}^{2}$ pada grafik isoterm Freundlich yaitu 0,96 dan 0,94 . Hal ini menunjukkan bahwa adsorpsi zat warna coklat pada permukaan arang aktif mengikuti kedua pola isoterm tersebut. Namun, nilai $\mathrm{R}^{2}$ pada pola isoterm Langmuir sedikit lebih besar dari nilai $\mathrm{R}^{2}$ pada pola isoterm Freundlich sehingga adsorpsi zat warna cokelat lebih mengikuti persamaan adsorpsi Langmuir. Hal ini menunjukkan bahwa adsorpsi zat warna oleh arang aktif kulit kopi pada air limbah pengolahan kopi hanya berlangsung satu lapis (monolayer) dan situs permukaannya bersifat homogen karena setiap situs aktif hanya dapat mengadsorpsi satu molekul. Masing-masing pori yang terdapat pada arang aktif kulit kopi hanya mampu mengikat satu molekul yang terdapat pada air limbah pengolahan kopi sehingga hanya membentuk satu lapisan (monolayer).

Pada persamaan isoterm Langmuir, nilai $\mathrm{Q}_{\mathrm{o}}$ menggambarkan kapasitas adsorpsi untuk membentuk lapisan sempurna pada permukaan adsorben sedangkan nilai $\mathrm{K}$ merupakan konstanta yang menunjukkan kekuatan ikatan molekul adsorbat pada permukaan adsorben. Pada persamaan isoterm Freundlich, nilai $\mathrm{n}$ menggambarkan intensitas dari proses adsorpsi, sedangkan nilai $\mathrm{K}_{\mathrm{f}}$ menunjukkan kapasitas adsorpsi dari adsorben. Nilai konstanta $Q_{0}, K, n$, dan $\mathrm{K}_{\mathrm{f}}$ dapat dihitung menggunakan persamaan isoterm Langmuir dan Freundlich yang terdapat pada Gambar 2. dan Gambar 3. Nilai konstanta yang dihasilkan dapat dilihat pada Tabel 6 .

Parameter adsorpsi isoterm Langmuir dan Freundlich yang telah didapatkan kemudian dimasukkan pada masing-masing persamaan. Persamaan isoterm Langmuir yaitu $Q_{e}=\frac{39,0625 \times 0,0018 \mathrm{C}}{0,00186 \mathrm{C}+1}$ dan isoterm Freundlich yaitu: $\mathrm{Q}_{\mathrm{e}}=0,55501 . \mathrm{C}^{\frac{1}{1,8089725}}$.

Tabel 7 menunjukkan hasil perhitungan Root Mean Square Error (RMSE), isoterm Langmuir mempunyai nilai RMSE sebesar 0,005 dan isoterm Freundlich mempunyai nilai RMSE sebesar 0,046. Nilai RMSE terkecil merupakan kriteria metode estimasi kesalahan pengukuran yang akurat (Widayati, 2013). Dengan kata lain, pada penelitian ini pengukuran isoterm Langmuir lebih akurat jika dibandingkan dengan pengukuran isoterm Freundlich. 


\section{KESIMPULAN}

Hasil pembuatan arang aktif kulit kopi dengan aktivator $\mathrm{NaOH} 1 \mathrm{M}$ telah memenuhi SNI 06-3730-1995 dengan nilai kadar air sebesar 3,43 \%; kadar abu sebesar 2,30 \%; dan daya serap iodium sebesar 15.231,6 mg/L. Adsorpsi arang aktif kulit kopi terhadap air limbah pengolahan kopi mengikuti kedua pola adsorpsi isoterm karena nilai $\mathrm{R}^{2}$ yang didapatkan tidak jauh berbeda yaitu 0,96 untuk isoterm Langmuir dan 0,94 untuk isoterm Freundlich. Namun, karena nilai $\mathrm{R}^{2}$ isoterm Langmuir lebih besar, maka isoterm Langmuir cenderung lebih sesuai dan nilai kapasitas optimum adsorpsi yang didapatkan yaitu sebesar $39,06 \mathrm{mg} / \mathrm{g}$ dengan persamaan $\mathrm{Q}_{\mathrm{e}}=\frac{39,0625 \times 0,0018 \mathrm{C}}{0,00186 \mathrm{C}+1}$.

\section{UCAPAN TERIMA KASIH}

Penulis menyampaikan terima kasih kepada pihak Jurusan Teknik Pertanian Fakultas Teknologi Pertanian Universitas Jember dan Agroindustri Kopi di Desa Sidomulyo Kecamatan Silo Kabupaten Jember yang telah memberikan dukungan berupa sarana dan prasarana sehingga penelitian dan penulisan artikel ini bisa selesai. Ucapan terima kasih juga disampaikan kepada reviewer yang memberikan saran dan masukan agar penyampaian hasil penelitian pada artikel ini lebih baik.

\section{DAFTAR PUSTAKA}

Aman, F., Mariana, M., Mahidin, M., \& Maulana, F. (2018). Penyerapan limbah cair amonia menggunakan arang aktif ampas kopi. Jurnal Litbang Industri, 8(1), 47-52. https:// doi.org/10.24960/jli.v8i1.3685.47-52.

BSN. (1995). SNI 06-3730-1995: Arang Aktif Teknis. Badan Standardisasi Nasional. Jakarta.

Cheruiyot, G. K., Wanyonyi, W. C., Kiplimo, J. J., \& Maina, E. N. (2019). Adsorption of toxic crystal violet dye using coffee husks: Equilibrium, kinetics and thermodynamics study. Scientific African, 5, e00116. https://doi.org/10.1016/j.sciaf.2019.e0 0116

Droste, R. L., \& Gehr, R.L. (2018). Theory and Practice of Water and Wastewater Treatment (2nd Ed.). Wiley.

Getachew, T., Hussen, A., \& Rao, V. M. (2015). Defluoridation of water by activated carbon prepared from banana (Musa paradisiaca) peel and coffee (Coffea arabica) husk. International Journal of Environmental Science and Technology, 12(6), 1857-1866. https://doi.org/10.1007/s13762-0140545-8.

Gonçalves, M., Guerreiro, M. C., Ramos, P. H., De Oliveira, L. C. A., \& Sapag, K. (2013). Activated carbon prepared from coffee pulp: potential adsorbent of organic contaminants in aqueous solution. Water Science and Technology, 68(5), 1085-1090. https://doi.org/10.2166/wst.2013.349.

Herlandien, Y. L. (2013). Pemanfaatan Arang Aktif Sebagai Absorban Logam Berat Dalam Air Lindi di TPA Pakusari Jember. [Skripsi, Universitas Jember]. https://repository.unej.ac.id/ handle/123456789/6254.

Kurniawan, A. \& Wicaksana, E. (2008). Uji coba Penjernihan Dan Penghilangan 
Bau Limbah Tapioka Dengan Menggunakan Arang Aktif Dari Tempurung Kelapa: Studi Aktivasi Dengan Pengasaman. [Skripsi, Jurusan Kimia Universitas Diponegoro]. Universitas Diponegoro. Semarang. http://eprints.undip.ac.id /1514/.

Malik, U. (2013). Alternatif pemanfaatan limbah industri pengolahan kayu sebagai arang aktif. Jurnal Aptek, 5(1), 63-70. https://doi.org/https://doi.org/ 10.30606/aptk.v5i1.74.

Mattel, C. L. (1991). Adsorption (2nd Edition). McGraw-Hill Company Inc. New York.

Murtihapsari, Mangallo, B., \& Handyani, D. D. (2017). Model isoterm freundlich dan langmuir oleh adsorben arang aktif bambu andong (G. verticillata (Wild) Munro) dan bambu ater (G. atter (Hassk) kurz ex Munro). Jurnal Sains Natural, 2(1), 17-23. https://doi.org/10.31938/jsn.v2i1.31.

Nekoo, S. H., \& Fatemi, S. (2013). Experimental study and adsorption modeling of COD reduction by activated carbon for wastewater treatment of oil refinery. Iranian Journal of Chemistry and Chemical Engineering, 32(3), 81-89. http://www.ijcce.ac.ir/article_5834.ht $\mathrm{ml}$.

Novita, E., Pradana, H. A., Wahyuningsih, S., Marhaenanto, B., Sujarwo, M. W., \& Hafid, M. S. A. (2019). Variasi digester anaerobik terhadap produksi biogas pada penanganan limbah cair pengolahan kopi. Jurnal Teknik Pertanian Lampung, 8(3), 164-174. http://dx.doi.org/10.23960/jtep-1.v8.i3 .164-174.

Pambayun, G. S., Yulianto, R. Y. E., Rachimoellah, M., \& Putri, E. M. M. (2013). Pembuatan karbon aktif dari arang tempurung kelapa dengan aktivator $\mathrm{ZnCl}_{2}$ dan $\mathrm{Na}_{2} \mathrm{CO}_{3}$ sebagai adsorben untuk mengurangi kadar fenol dalam air limbah. Jurnal Teknik Pomits, 2(1), 116-120. https://doi.org /10.12962/j23373539.v2i1.2437.

Puspitasari, A. A., Sumarni, N. K., \& Musafira, M. (2017). Kajian kapasitas adsorpsi arang aktif kulit kopi robusta teraktivasi $\mathrm{ZNCl} 2$ terhadap ion $\mathrm{Pb}$ (II). Kovalen, 3(2), 134-141. https://doi.org /10.22487/j24775398.2017.v3.i2.8719

Riadi, L., Hwa, L., \& Sukharaharja, A. (2011). Kinetika penghilangan warna pada limbah kopi menggunakan foto fenton. Jurnal Purifikasi, 12(3), 1-8. https://doi.org/10.12962/j25983806.v 12.i3.73.

Sari, M. F. P., Loekitowati, P., \& Mohadi, R. (2017). Penggunaan karbon aktif dari ampas tembu sebagai adsorben zat warna procion merah limbah cair industro songket. Jurnal Pengelolaan Sumberdaya Alam dan Lingkungan, 7(1), 37-40. https://doi.org/10.29244 /jps1.7.1.37-40.

Ukanwa, K. S., Patchigolla, K. Anthony, E., \& Mandavgane, S. (2019). A review of chemicals to produce activated carbon from agricultural waste biomass. Sustainability (Switzerland), 11(6204), 1-35. https://doi.org/ $10.3390 /$ su11226204.

Tamad \& Maryanto, J. (2014). Desain multi soil layering (MSL) biomineral untuk penyaringan limbah cair kilang minyak guna air irigasi. Agrin, 18(2), 181-188. http://dx.doi.org/10.20884/ 1.agrin.2014.18.2.223.

Wardhana, I. W., Siwi, D. W., \& Ika, D. R. (2013). Penggunaan karbon aktif dari sampah plastik untuk menurunkan kandungan phospat pada limbah cair (studi kasus: limbah cair industri laundry di tembelang, Semarang). Presipitasi, 10(1), 30-40. https:// doi.org/10.14710/presipitasi.v10i1.3040.

Widayati, C. S. (2013). Komparasi beberapa metode estimasi kesalahan 
pengukuran. Jurnal Penelitian dan Evaluasi Pendidikan, 13(2), 182-197. https://doi.org/10.21831/pep.v13i2.14 09.

Widyotomo, S. (2013). Potensi dan teknologi diversifikasi limbah kopi menjadi produk bermutu dan bernilai tambah. Review Penelitian Kopi dan Kakao, 1(1), 63-80. https://www. scribd.com/doc/250141770/5-SksnFINAL-Sksn-Rev.

Wijayanti, I. E., \& Kurniawati. E. A. (2019). Studi kinetika adsorpsi isoterm persamaan langmuir dan freundlich pada abu gosok sebagai adsorben. EduChemia, 4(2), 175-184. https:// doi.org/10.30870/educhemia.v4i2.611 9.

Yeni, S., Heltina, D., \& Yeni, E. (2008). Pemanfaatan arang tulang sebagai adsorben alternatif untuk proses penyerapan rhodamine B. Seminar Nasional Teknik Kimia Oleo dan Petrokimia Indonesia 2008, 1-8. https://repository.unri.ac.id/xmlui/bits tream/handle/123456789/7952/B11.p df? sequence $=1$. 